\title{
COLLABORATIVE ENGLISH LANGUAGE LEARNING: SOME REFLECTIONS FROM INTERACTIONS BETWEEN PAIRS'
}

\section{APRENDIZAGEM COLABORATIVA DE LÍNGUA INGLESA: ALGUMAS REFLEXÕES A PARTIR DE INTERAÇÕES ENTRE PARES}

\author{
Laryssa Paulino de Queiroz Sousa* \\ Fernanda Franco Tiraboschi ${ }^{\star \star}$ \\ Neuda Alves do Lago ${ }^{* * *}$ \\ Francisco José Quaresma de Figueiredo ${ }^{* * *}$
}

\begin{abstract}
The focus of this study is on the interactions five pairs of students had in order to carry out a collaborative writing activity. The research was conducted in a language school of Goiânia, in Goiás, Brazil, with ten EFL/ESL students, in 2015. The objectives of this investigation are: a) to observe and discuss the elements that stand out during the students' interactions; and b) to investigate these learners' perceptions of the experience. This study is grounded on sociocultural theory (DONATO, 1994; HALL, 2001; VYGOTSKY, 1978) and collaborative language learning (FIGUEIREDO, 2005, 2006, 2008, 2015; OXFORD, 1997). The theoretical assumptions that guide this research consider interaction and collaboration as essential elements for language learning development. This is a qualitative case study (GODOY, 2006; TELLES, 2002), and the sources used to generate the data are questionnaires, audio recordings of the students' interactions and semi-structured interviews. The elements that stand out in this investigation are related to the potentialities of dialogic interactions, which foster scaffolding, mutual support, and the promotion of learners' autonomy. In addition, the learners highlight some positive aspects they could perceive from the experience, such as each other's help and the possibility to access more ideas; as negative aspects, they point out disagreements and conflicts they had to handle during the interactions.
\end{abstract}

Keywords: Sociocultural theory; collaborative language learning; interactions between pairs.

1. Thanks to the Coordenação de Aperfeiçoamento de Pessoal de Nível Superior (CAPES) for its financial support in order to develop this research.

* Universidade Federal de Goiás (UFG), Goiânia, Goiás, Brasil. laryssa.paulino1@gmail.com

** Universidade Federal de Goiás (UFG), Goiânia, Goiás, Brasil. nandafranco87@yahoo.com.br

*** Universidade Federal de Goiás (UFG), Goiânia, Goiás, Brasil. neudalago@ @otmail.com

**** Universidade Federal de Goiás (UFG), Goiânia, Goiás, Brasil. fquaresma@terra.com.br 


\section{RESUMO}

Este estudo tem como foco as interações que cinco pares de alunos tiveram, ao realizar uma atividade de escrita colaborativa. A pesquisa foi realizada em uma escola de idiomas de Goiânia, em Goiás, no Brasil, com dez alunos de língua inglesa, em 2015. Os objetivos desta investigação são: a) observar e discutir os elementos que se destacam durante as interações dos alunos; e b) investigar as percepções desses aprendizes sobre a experiência. Este estudo é fundamentado na teoria sociocultural (DONATO, 1994; HALL, 2001; VYGOTSKY, 1978) e na aprendizagem colaborativa de línguas (FIGUEIREDO, 2005, 2006, 2008, 2015; OXFORD, 1997). Os pressupostos teóricos que norteiam esta pesquisa consideram a interação e a colaboração como elementos essenciais para o desenvolvimento da aprendizagem de línguas. Trata-se de um estudo de caso qualitativo (GODOY, 2006; TELLES, 2002), e as fontes utilizadas para a geração dos dados são questionários, gravações de áudio das interações entre os alunos e entrevistas semiestruturadas. Os elementos que se destacam nesta investigação estão relacionados às potencialidades das interações dialógicas, que fomentam o scaffolding, o apoio mútuo e a promoção da autonomia dos aprendizes. Além disso, os aprendizes destacam alguns aspectos positivos que puderam perceber a partir da experiência, como o auxílio um ao outro e a possibilidade de acessar mais ideias; como aspectos negativos, apontam as divergências e os conflitos com os quais tiveram que lidar durante as interações.

Palavras-chave: Teoria sociocultural; aprendizagem colaborativa de línguas; interações entre pares.

\section{INITIAL CONSIDERATIONS}

This study is grounded on principles of sociocultural theory (DONATO, 1994; HALL, 2001; VYGOTSKY, 1978) and collaborative language learning (FIGUEIREDO, 2005, 2006, 2008, 2015; OXFORD, 1997). Thus, elements such as the Zone of Proximal Development (ZPD) (ALJAAFREH; LANTOLF, 1994; FIGUEIREDO, 2006; VYGOTSKY, 1998) and scaffolding (DONATO, 1994; FIGUEIREDO, 2006; WOOD; BRUNER; ROSS, 1976) are essential constructs for this investigation. The focus of this research is on the interactions that occurred between each pair of students, while working on a collaborative writing production. This study was conducted in a language school of Goiânia, in Goiás, Brazil, with ten EFL/ESL ${ }^{2}$ students, in 2015.

For Vygotsky (1978), language is an interpersonal and intrapersonal psychological instrument, used to mediate interactions and communication among people and to aid individuals' cognitive development. According to the

2. Although there have been many discussions about the uses of terms such as EFL and ESL, as well as their implications (JORDÃO, 2012; KUMARAVADIVELU, 2014), in this study, the people addressed as EFL/ESL students are learners that simply have Portuguese as their mother tongue and, in 2015, were also learning English. 
sociocultural perspective, exchange and interaction among learners is essential for language learning development (FIGUEIREDO, 2006, 2015; LIGHTBOWN, SPADA, 1993; SWAIN, 1995), and students are perceived as active agents in their learning (FIGUEIREDO, 2008; RUBIN, 1987; SWAIN, 1995).

The general objective of the study is to provide empirical material for the discussion of aspects concerning collaborative language learning. The specific objectives of this research are: a) to observe and discuss the main elements that stand out during the students' interactions, while they worked on a collaborative writing activity; and b) to investigate the students' perceptions of the experience.

This investigation is characterized as a qualitative research, in which things are studied in their natural context (in this case, English language learning in a classroom) and phenomena are addressed in terms of the meanings people convey (DENZIN, LINCOLN, 2003; MELLO; REES, 2011). More specifically, this is a case study (GODOY, 2006; TELLES, 2002), for it aims to investigate a single case, in order to gather detailed information on the experience.

\section{SOCIOCULTURAL THEORY AND COLLABORATIVE LANGUAGE LEARNING}

Language is fundamentally social and, thus, when we learn through communication, interaction and dialogue, we experience interpsychological processes, which are internalized and lead to intrapsychological processes (DONATO, 1994; FIGUEIREDO, 2005, 2006; SWAIN, 1995; VYGOTSKY, 1978). Therefore, a person's development occurs firstly on the social level, and sequentially on the individual level, that is, it first happens among people and then within the person.

Vygotsky (1978) characterizes the actual development level as what the individual can do by herself/himself and the potential development level as what s/he can do when aided by someone else. He defines the Zone of Proximal Development (ZPD) as

[...] the distance between the actual development level as determined by independent problem solving and the level of potential development as determined through problem solving under adult guidance or in collaboration with a more capable peer. (VYGOTSKY, 1978, p. 86).

Therefore, instead of focusing on what people can do by themselves, the author concentrates on what they can do when helped by someone else. As Wells (1999, as cited in FIGUEIREDO, 2015) highlights, regardless of the fact whether 
there is a more capable peer or not, by working in collaboration learners can solve problems that perhaps they could not, if they were working on them by themselves.

Another concept closely related to the Zone of Proximal Development is scaffolding, characterized by Wood, Bruner and Ross (1976) as a process of assistance from one individual to another, in which another person's help is essential for the development of a certain task. For Aljaafreh and Lantolf (1994), scaffolding must be gradual, contingent and dialogic, being adapted according to the needs of interactions. In language learning environments, scaffolding happens, for example, when students question each other's utterances, make suggestions, ask for clarification, and aid each other's language knowledge (DOBAO, 2012; FIGUEIREDO, 2005; STORCH, 2001).

Ergo, by interacting, everyone has the chance to learn something new. Thus, knowledge is co-constructed (DOBAO, 2012; DONATO, 1994; FIGUEIREDO, 2005, 2006, 2008, 2015; SWAIN, 1995). This study is based on the premises aforementioned, for the participants in this investigation worked collaboratively in pairs, aiding one another in their language learning process throughout the experience. Vygotsky (1978), Scarcella and Oxford (1992), Donato (1994), Swain (1995) and Figueiredo $(2005,2006,2008,2015)$ underscore the benefits of interactions among learners, as they are both sources of input and output, which might hugely contribute to students' cognitive development. According to them, language learning happens in a context that provides dialogic interaction. Therefore, the social context influences learners' individual linguistic development (DOBAO, 2012; DONATO, 1994; FIGUEIREDO, 2005; VYGOTSKY, 1978).

Figueiredo $(2006,2015)$ states that collaborative learning is based on the principles of sociocultural theory. It is a constructivist approach that involves educational situations in which two or more people try to learn something together, aspect which characterizes this investigation. Hence, in collaborative interactions, the people involved aim to co-construct knowledge, and that might result in linguistic changes (DOBAO, 2012; DONATO, 1994; FIGUEIREDO, 2005, 2006, 2008, 2015). According to Figueiredo (2006), collaborative learning has the following characteristics: a) focus on the process and on students; $b$ ) implementation of activities that are nonstructured, in the sense they allow students to appropriate different roles during the experience; ${ }_{i}$ ) learners' active roles and promotion of their autonomy $;$ d) the learning process as a shared experience among the people involved in it; and e) the development of social and cognitive skills.

In addition, based on Tinzmann et al. (1990), High (1993), Aoki (1999), and Ghaith (2002), Figueiredo (2006) underscores that, in collaborative interactions 
that promote language learning, students: a) have access to input and output; b) conduct negotiations, as learners strive to communicate and to carry out the task proposed; c) create a supportive environment, in which there is positive interdependence (other-regulation) that might lead to autonomy (self-regulation); and d) share knowledge and information. The staff of the language school where the study was undertaken considers collaboration (between teachers and teachers, students and students, and teachers and students) as an essential element when teaching and learning languages. However, the context of this investigation was prepared and the activity proposed was designed for students to develop a specific collaborative writing activity, an experience that later was analyzed by the authors of this article. In our analysis, we consider all the elements previously mentioned and seek to relate them to our own findings.

Harris (1992) defines collaborative writing as textual productions written by at least two authors. In the context of this study, the teacher proposed a collaborative writing activity so that the students could have an experience of collaborative language learning.

\section{THE STUDY}

This research is characterized as a qualitative case study. Qualitative research is based on a naturalistic and interpretive approach and the focus is on the meanings generated from the experience investigated (DENZIN, LINCOLN, 2003; MELLO; RESS, 2011). A case study focuses on a single case and attempts to gather as much information as possible about the specific phenomena examined, in order to better understand its specificities (GODOY, 2006; TELLES, 2002).

This investigation was carried out at a language school in Goiânia, Goiás, a state in the Midwest of Brazil, with a group of ten elementary EFL/ESL students, on June 20, 2015, and it lasted three hours. Taking into account that the aims of this study are to investigate what elements stand out during the students' collaborative pair interactions and their perceptions of the experience, the sources used to generate the data were: a) initial questionnaires, which were designed to collect general information about the participants (name, pseudonym, age and sex), as well as to inquire about their interest in writing and if they had ever written texts in pairs (Appendix A); b) recordings of the interactions between the pairs during the collaborative writing of their texts; and c) semi-structured interviews, which were utilized to register the students' perceptions of the activity proposed (Appendix B). 
Questionnaires are used to collect information on a particular aspect (RICHARDS, LOCKHART, 1996), such as students' previous experiences with collaborative writing and their interest in the writing skill, as it was asked for this study. Besides that, audio recordings were employed in order to obtain a comprehensive account of the students' interactions (RICHARDS; LOCKART, 1996). Semistructured interviews are utilized due to their relative flexibility to make adaptations when deemed necessary by the interviewer (BELL, 2008); and for this research, specifically, they were used so the students could individually talk to the interviewer about the experience they had had, and consequently express their perceptions and opinions right after they had done the activity with their classmates.

The school where the research was done is located in a middle-class neighborhood, and students from low and middle classes attend it. It is known in the region for its affordable fees and quality education. Such aspects are directly related to the ideology of the group that manages the school, which aims to provide education for people from lower classes at lower costs. The classes given are mainly based on the premises of communicative teaching; however, that does not prevent the teachers from resorting to other approaches that they see fit, considering the needs of their students.

The teacher who had her group's interactions analyzed is the first author of this article. She took a subject whose focus was on collaborative language learning and then decided to prepare an activity for her students based on it. The learners that participated in this investigation, in 2015, had had theretofore four semesters of English language classes (totalizing around 160 hours of instruction), that is, two years of lessons, given weekly, on Saturdays, from $02 \mathrm{~h} 00$ p.m. to 05h30 p.m. According to the Common European Framework of Reference for Languages: Learning, Teaching, Assessment (CEFR), their English language knowledge would be classified as A2, that is, as elementary English language students. Thitherto, they were already familiar with collaborative work in tasks proposed by teachers at that institution, as working collaboratively was already something characteristic of that school.

The table below presents the students' general data collected through the questionnaires:

Table 1. Study participants

\begin{tabular}{|c|c|c|c|}
\hline Pseudonym & Sex & Age & Pairs \\
\hline Alice & F & 14 & Alice and Gina \\
\hline Gina & F & 14 & \multirow{2}{*}{ Cecília and Paulo } \\
\hline Cecília & F & 14 & \\
\hline Paulo & M & 30 & \\
\hline
\end{tabular}




\begin{tabular}{|c|c|c|c|}
\hline Maju & F & 17 & Maju and Carolina \\
\hline Carolina & F & 26 & \multirow{2}{*}{ Yara and João } \\
\hline Yara & F & 19 & \\
\hline João & M & 23 & Lílian and Samanta \\
\hline Lílian & F & 20 & \\
\hline Samanta & F & 28 & \\
\hline
\end{tabular}

Source: Prepared by the authors, based on the questionnaires.

The activity proposed by the teacher was the development of a written production in pairs, in a class. This activity ranged from thirty to sixty minutes, among the pairs. Thus, after the learners individually responded to the questionnaires, the researcher handed out twenty images of a character's daily routine to each pair (Annex A). The images used were taken from Peter Watcyn-Jones's book entitled Vocabulary 1: Games and activities (WATCYN-JONES, 2001). The activity proposed in the book is about matching the images with sentences, also provided in another worksheet. Therefore, the teacher simply used the images of the activity for her learners to develop a written production. The students had previously studied the simple present tense and vocabulary related to daily routine, and by doing the activity proposed they had the chance to practice the structures and words learned. This was the final activity of that semester.

Their task was to organize the images, as they saw fit and, after that, they were supposed to create a story and write it together. The pairs were chosen randomly by means of a draw (their names were written on pieces of paper and put inside a container, and then the teacher picked two names to form each pair at a time). This choice was made so students could work with classmates they would not normally pair up with; as a result, the development of this activity with that group aided in creating a better atmosphere among the students. In addition to the guidelines already mentioned, the teacher did not provide further instructions. The educator recorded in audio all interactions that occurred between the pairs during the activity for later analysis. Sequentially, after doing the activity, the students were interviewed individually by the teacher.

For the transcription ${ }^{3}$ of the data generated in this study, the following symbols were used:

3. The linguistic repertoire used for the transcriptions of the utterances in Portuguese, from the interviews, are an approximation of the standard written language, since these are informal interviews with the students. This choice is justified because the focus of the analysis is on the discourses produced by the participants. The interactions between the pairs, predominantly in English, are transcribed verbatim, taking into account the fact that they are elementary ESL/EFL learners. 
Table 2. Transcription symbols

\begin{tabular}{|c|c|}
\hline Symbols & Meanings of the symbols \\
\hline Italics & Parts spoken in Portuguese by the students \\
\hline UPPER CASE & Emphasis \\
\hline$[\ldots]$ & Parts suppressed \\
\hline[] & Translations ${ }^{4}$, complements and comments made by the researchers \\
\hline$\ldots$ & Learners' pauses or incomplete utterances \\
\hline
\end{tabular}

Source: Prepared by the authors, based on Dionísio (2001).

\section{DATA ANALYSIS}

The data analysis and its discussion are divided into two subsections: a) focus on the interactions between the pairs, which were recorded; and b) the students' perceptions of the experience, which are drawn from their questionnaires and, mainly, from their interviews.

\subsection{Focus on the interactions between the pairs}

In the following two excerpts, it is possible to observe the students' coconstruction of knowledge and negotiation of form in order to write their texts, as well as how they deal with their classmates' mistakes

\section{Excerpt 01}

(1) Paulo: Because don't pay attention, don't give...

(2) Cecília: Mark DOESN’T.

(3) Paulo: Doesn't, doesn't.

(4) Cecília: Doesn't give attention. How can I...?

(5) Paulo: Double T. [referring to the word "attention".]

(6) Cecília: Is double T?

(7) Paulo: Yes.

Excerpt 02

(1) Carolina: John go to sleep.

(2) Maju: Go or goes?

(3) Carolina: Go? Goes, goes!

4. The translations from Portuguese into English are only made at moments when the meanings of the words are not available in the context or at moments when the whole utterances are in Portuguese.

5. An approximation of the English standard language is the linguistic repertoire used as reference by the students in order to assess what would be considered mistakes and what would not. 
(4) Maju: Goes.

(5) Carolina: John goes to sleep [...].

(Source: Interactions between the pairs, June 20, 2015)

In excerpts 01 and 02, it is visible how students regulate each other's utterances. According to Vygotsky (1978), other-regulation, which is an interpsychological activity, concerns the assistance one gives to another in order to perform a task; self-regulation, which is an intrapsychological activity, is about independently performing a task. The Zone of Proximal Development is present in other-regulation experiences. Thereby, through dialogic interactions, learners can scaffold each other's language development (DONATO, 1994; FIGUEIREDO, 2005, 2008; STORCH, 2001). In this perspective, Hall (2001, p. 18) underlines that by interacting students "assimilate and internalize knowledge of linguistic forms in the target language", as they "expand their L2 knowledge and extend the linguistic development of their peers" (DONATO, 1994, p. 52).

In collaborative learning activities, students teach and learn with and from each other (FIGUEIREDO, 2005, 2008; FIGUEIREDO; ASSIS, 2006). In Wertsch's words (1979, as cited in DONATO, 1994, p. 41), "scaffolded performance is a dialogically constituted interpsychological mechanism that promotes" learners' "internalization of knowledge co-constructed in shared activity". In excerpts 01 and 02 , there are examples of how knowledge is actively co-constructed by learners, which might result in linguistic changes. Throughout these students' interactions, it is possible to observe the effects of their classmates' corrections on their language production.

Swain (1995, p. 136) complements that the process of co-construction of knowledge "becomes particularly observable for language development when the task students are engaged in involves reflecting on their own language production, that is, when they are engaged in negotiating about form". In the first excerpt, Cecília draws Paulo's attention to the structure of the third person singular in the simple present tense, in the negative form, in line 2, and in the second excerpt, Maju questions Carolina about the same structure, but in the affirmative form, in line 2. In addition, still in the first excerpt, Paulo helps Cecília with the spelling of the word attention, in line 5 .

As Mclaughlin (1987, p. 50) argues, "[u]nless learners try out the language, they are unlikely to get the kind of feedback they need to analyse the structure of the language". In excerpt 02, Carolina and Maju negotiate their output, as they produce some forms of language that they have not yet fully learned. In the process of negotiation, students modify their output in response to their conversational 
partners' questions, as Carolina does as a reaction to Maju’s questioning, in excerpt 02 .

Another aspect that needs to be highlighted is that the students' interactions took place in a learning environment, characterized as a formal setting (ELLIS, 1985; FIGUEIREDO, 2015). In this kind of context, in several moments, learning another language requires a conscious knowledge of the rules of the target language, which is aided by the correction of mistakes and errors ${ }^{6}$. As Figueiredo $(1999,2005)$, Figueiredo and Assis (2006) and Silva and Figueiredo (2006) point out, errors and mistakes are a part of any learning process and correction should be used to show ways to improve learning. For these authors, when students make mistakes, they show what they have learned and what they have not, which can help the teacher to focus on specific language aspects that need to be more studied and practiced for internalization.

In excerpt 02, when Cecília notices Paulo's mistake, she makes use of direct correction (SILVA; FIGUEIREDO, 2006), that is, she makes the correction right after she notices his mistake. All participants of this investigation, as the ones in Silva and Figueiredo's study (2006), showed they were receptive to corrective feedback, as they perceived it as a kind of support that could lead them to avoid making the same mistakes repeatedly. In this kind of situation, correction can be characterized as a moment of interaction and learning (SCARCELLA; OXFORD, 1992; SILVA; FIGUEIREDO, 2006; STORCH, 2005).

In this study, during a considerable amount of time, the learners tried to help each other by aiding them in learning and internalizing grammar rules and vocabulary, as it happens in Figueiredo's study (2005). However, they also assisted their peers with other aspects related to sentence structures and pronunciation, and negotiated the content of their texts and procedures in order to carry out the task. According to Figueiredo (2005), as learners correct each other, they become more active in their own language learning process.

For Figueiredo (1999), most mistakes students make are the result of conscious or unconscious attempts to use language they have already learned, as an endeavor to learn even more. As it can be noted in excerpts 01 and 02, when students interact and make corrections of deviations they perceive in each other's utterances, they also experience genuine communication, although it might be focused on language form. In the interaction between Maju and Carolina, it is possible to perceive how

6. According to Corder (1967), mistakes are deviations that happen when students fail to use their language knowledge, and errors are deviations that occur due to their lack of knowledge of specific aspects of that language. 
the mistakes one makes can shed light on another's doubts. Thereby, students can learn through the correction of their own mistakes as well as of their classmates'.

Repetition of each other's utterances can be a strategy that aids internalization of forms, as students tried to do in this study. As it is possible to see in the interaction between Cecília and Paulo, in excerpt 01, she makes a correction in Paulo's speech, and he shows he agrees with her by repeating the modified sentence structure provided by Cecília. Something similar happens in the interaction between Maju and Carolina, in excerpt 02. Therefore, after being corrected, Paulo and Carolina show a positive attitude towards their peers' corrections. According to Lightbown and Spada (1993), imitation of new words and sentence structures is a strategy used by learners so that such elements can become a part of their language system. It is relevant to add that besides vocabulary and grammar structures, the learners who participated in this investigation also used this strategy to work on their pronunciation and intonation, as their peers also made corrections regarding them.

In the following excerpts, there are examples of private speech, used by the students as attempts to self-regulate:

\section{Excerpt 03}

(1) Samanta: This... [showing the image.]

(2) Lílian: What?

(3) Samanta: This! [referring to the image.] Watch TV.

(4) Lilian: Yeah. He is in the couch, watch TV and he has a letter in her hand, in his hand, and here [poiting at another image] he is opening the letter.

Excerpt 04

(1) Cecília: So...

(2) Paulo So...

(3) Cecília: He doesn't has. He doesn't have. Because the auxiliary verb is do. He doesn't have time...

(Source: Interactions between the pairs, June 20, 2015)

Concerning linguistic aspects, Swain (1995) explains that by producing output, students can: a) practice language, which consequently can enhance fluency; b) test out hypotheses, which can invoke feedback from themselves or others in order to modify what was said ${ }_{i}$ ) become aware of their knowledge gaps, which might prompt them to consciously recognize some of their linguistic problems; and d) reflect on their own language production, which might generate linguistic knowledge that is new for them. In excerpts 03 and 04, Lílian's and Cecília's utterances, in lines 4 and 3 , respectively, it is perceivable how the functions of 
output performed their roles, as the learners' linguistic productions lead them to reflect on their own utterances, and make adjustments, insofar they realize their mistakes.

In these excerpts, there are examples of what Donato (1994, p. 47) defines as "self-initiated attempts to control and internalize the needed knowledge." As the author states, private speech happens when students' utterances are directed to no one other than themselves, as attempts at self-guidance in order to undertake an activity. Students' knowledge of the target language changes as they interact (DONATO, 1994; FIGUEIREDO; ASSIS, 2006), as they carry out self-repair (SCARCELLA OXFORD, 1992), and attempt to internalize something they have not yet fully acquired - that it is clear in Lilian's and Cecília's utterances, in excerpt 03, line 4, and in excerpt 04, line 3, respectively. According to Figueiredo (2005, 2008), students might use private speech with the intention of reflecting on their own utterances. Rubin $(1987$, p. 17) affirms that "it is essential for students to be able to assess their own knowledge", that is, monitoring is essential to learning, as students realize their own mistakes and then make corrections.

Scarcella and Oxford (1992), Donato (1994) and Figueiredo (2005) add that the social context in which there is interaction and collaborative learning can foment private speech, and accordingly provoke linguistic development and internalization of knowledge.

In excerpts 05 and 06 , the students' use of their $\mathrm{L} 1$ as scaffolding, metalanguage and some other reflections on interaction and negotiation are addressed:

Excerpt 05

(1) Gina: And start...

(2) Alice: And start...

(3) Gina: ...to read?

(4) Alice: Yes.

(5) Gina: Começou. [Started.]

(6) Alice and Gina: Started.

(7) Gina: Started...

(8) Alice: To read, I think.

(9) Gina: Yes, because is one pair - two verbs. And started to read.

(10) Alice: And started to read, eh...

Excerpt 06

(1) Lílian: And then he goes to the bathroom. [...] And brushes his...

(2) Samanta: Teeth. É porque é plural. [It's because it's plural.]

(3) Lílian: Tooth, teeth. Which one is the plural? 
(4) Samanta: Teeth. It's like foot and feet. Foot is one. Feet is two.

(5) Lílian: Ah, é. [it is.]

(Source: Interactions between the pairs, June 20, 2015)

In excerpts 05 and 06 , the students show their knowledge of rules explicitly and discuss them, which is something characteristic of a learning environment (FIGUEIREDO, 2008, 2015), in this case a classroom.

Based on Brooks and Donato (1994), Antón and Dicamilla (1999), Cook (2001), among others, Figueiredo (2006, p. 25) underlines that " $[\ldots]$ the use of L1 should not be seen as an impediment to learning the new language, but rather as scaffolding used by students to facilitate this process. ${ }^{\prime 7}$ In excerpt 05 , line 5, Gina's uses her L1 as a cognitive strategy to help her reflect on the correct verb tense; in this case, the L1 is used as scaffolding to help her understand what happens in the target language she is learning. Both Gina and Alice could readily produce the correct verb form in the past in English, in line 6, after they were aided by their mother tongue. What Gina does is to use her L1 as a language learning strategy in order to help herself in her target language learning development. Students' L1 is "permanently present in their minds" (COOK, 1999, p. 202), and students resort to it at moments of some kind of difficulty (ELLIS, 1985; FIGUEIREDO, 2005, 2008).

Furthermore, according to Figueiredo $(2005,2008)$, learners usually use their L1 in order to try to make themselves clearer and to keep the interaction going, as Samanta probably does in excerpt 06 , line 2 . When she uses her $\mathrm{L} 1$ as scaffolding to aid her interaction with Lílian, she is making use of a learning strategy (OXFORD, 1990; RUBIN, 1987). In Cook's words (1999, p. 201), "[w]hen students need the meaning of a new word or grammatical structure, they can access it through translation into their L1." As the author claims, students use their mother tongue for communication during classroom activities, as it happens in excerpts 05 and 06.

In excerpt 05 , in line 09 , and in excerpt 06 , in lines 2,3 , and 4 , the students resort to metalanguage. According to Swain (1995), one of the functions of output is to reflect on language and its form - the metalinguistic function. Thus, besides testing out their hypotheses on language, they can use language to discuss itself, "allowing learners to control and internalize it" (SWAIN, 1995, p. 132). In the author's words,

7. Original quote: "[...] o uso da L1 não deve ser visto como um impedimento para a aprendizagem da nova língua, mas como um scaffolding utilizado pelos alunos para facilitar esse processo" (FIGUEIREDO, 2006, p. 25). 
[...] it is certainly feasible for a communicative task to be one in which learners communicate about language, in the context of trying to produce something they want to say in the target language. Learners negotiate meaning, but the content of the negotiation is language form; and its relation to the meaning they are trying to express; they produce language and they reflect upon it. They use language to 'negotiate about form'. (SWAIN, 1995, p. 133, emphasis in original).

For Swain (1995), the metalinguistic function is an element that can promote learning. In addition, when students explain something to each other, like Gina and Samanta do in their interactions with Alice and Lílian, respectively, they can increase their comprehension of the subject.

According to Scarcella and Oxford (1992), Donato (1994), Swain (1995) and Figueiredo $(2006,2015)$, interaction facilitates language development. Students learn through and in the interactions in which they participate (DONATO, 1994; FIGUEIREDO, 2006, 2015; SWAIN, 1995). In Scarcella and Oxford's words (1992, p. 35), "[1]anguage-promoting interaction occurs when learners assist one another while communicating. Where language performance is assisted by more capable others, the second language develops."

In excerpts 05 and 06, besides developing their speaking and listening skills, as well as writing and reading skills (insofar the focus of their interactions was on their text productions), through their interactions, learning was taking place. Moreover, in several moments the students provided assistance to one another in a similar way any teacher would. As Donato (1994, p. 46) points out, activities focused on interaction, in which students scaffold each other's language development, indicate "the presence of distributed help and mutual orientation to the task."

The following excerpt illustrates, in general, how the teacher's participation was during the development of the activity done by the pairs, as well as the students' engagement with each other's language learning development:

\section{Excerpt 07}

(1) Yara: He reads, no, check.

(2) João: Checks.

(3) Yara: Checks his correspondência. [mail.] [She looks at her classmate, expecting him to know this word in English.]

(4) João: I'm thinking about it.

(5) Yara: Teacher, how can I say correspondência?

(6) Teacher: Mail.

(7) Yara: How can I spell?

(8) João: M-A-I-L.

(9) Yara: His mail. He watches TV. He goes to bed? 
(10) João: No, wait.

(11) Yara: He reads a book?

(12) João: He sets the alarm clock.

(13) Yara: He?

(14) João: Sets, sets. S-E-T-S.

(15) Yara: He sets the?

(16) João: Alarm clock.

(17) Yara: The alarm clock.

(18) João: Do you know what "sets" mean in this case?

(19) Yara: No. He sets.

(20) João: No. Answer my question: do you know what "sets" mean?

(21) Yara: I don't understand.

(22) João: Do you know what "set" means in this case?

(23) Yara: No.

(24) João: Configurar. In this case, "sets" means configurar.

(25) Yara: Ah, OK.

(Source: Interactions between the pairs, June 20, 2015)

In the context of collaborative learning, the teacher's role is to mediate the students' leaning process, aiding them, when required (FIGUEIREDO, 2006). According to Scarcella and Oxford (1992), the teacher helps students with elements they need in order to express themselves the way they want, that is, the teacher provides scaffolding. During all the interactions between the pairs, the students only asked for the teacher's help at moments of extreme necessity, that is, before asking the teacher, they would resort to other classmates for help, from other pairs. Line 6, in excerpt 07, represents the kind of contribution the teacher made in this study. Figueiredo (2005) adds that teachers can perform their roles as mediators when students cannot solve certain problems by themselves, and thus require somebody else's help.

Oxford (1990) states that in a collaborative learning environment it is likely for students to show their concern for each other, as it happens in excerpt 07. João shows clear interest in Yara's language learning development, as he realizes his classmate did not know the word he had used and then tries to teach it to her. What is noteworthy in their interaction is that he interrupts the development of the activity so he can teach her a new word. Thereby, by stepping aside, the teacher makes it possible for students "to become autonomous and to assume an active and meaningful role in the learning process" (FIGUEIREDO, 2008, p. 122). 


\subsection{The students' perceptions of the experience}

The focus of this subsection is on the positive and negative aspects mentioned by the participants in relation to the collaborative writing activity done in pairs.

Regarding the questionnaires, before doing the activity proposed by the teacher, the students were asked if they liked writing or not. João and Yara were the only ones who stated that they did not. In addition, Alice and Maju claimed they had already worked with collaborative writing at least once. From the ten students, only Gina affirmed she thought collaborative writing would not work for her due to the fact she preferred to work alone. However, as it is shown in the following excerpt, after the experience with Alice, Gina changed her mind. In addition, Cecília also shares some of her perceptions concerning the positive aspects of the experience.

Pesquisadora: $\mathrm{O}$ que você achou da atividade de escrita/produção do texto em pares? [Researcher: What do you think of the activity you did in pairs?]

\section{Excerpt 08}

Gina: Agora que a gente fez [a atividade], eu consegui ver que é muito legal, porque dá para a gente ajudar um ao outro. Quando a gente faz sozinba, essa son eu pensando, né? "Eu escrevo melhor sozinha. Eu prefiro". Mas, quando en vi que a gente fez juntas [o desenvolvimento do texto], eu acho que melhorou bastante em relação a escrever sozinha. Por exemplo, às vezes eu não sei a palavra, ela sabe, aí escrevo. Às vezes en escrevo errado e ela fala: "Você escreveu errado", aí ela vai e me ajuda. Quando en estou sozinha, não, en escrevo errado, vai ficar, porque não tem ninguém para me ajudar. Em pares ficou muito mais fácil para fazer a atividade.

[Gina: Now, after we did [the activity], I could see how nice it is, because we could help each other. When we do it alone, that's me thinking, right? "I can write it better on my own. I prefer it this way". But when I saw we did it together, I think it [the development of the text] got much better, in relation to writing alone. For example, sometimes I don't know a word, she does, then I write it. Sometimes I make a mistake, then she says, "You made a mistake", then she helps me with it. But when I am alone I make those mistakes, and they won't be corrected, because there's nobody to help me. Doing the activity in pairs was much easier.]

\section{Excerpt 09}

Cecilia: Eu achei bem interessante, principalmente, pordue um ajuda o outro. E eu pude perceber que, sempre quando eu colocava alguma coisa errada, ele me corrigia e [quando] ele escrevia alguma coisa errada, eu também o corrigia. Então, achei, assim, bem legal e interessante.

[Cecilia: I found it really interesting, mainly because we helped each other. And I could realize that every time I made a mistake, he corrected me, and [when] he made a mistake, I corrected him too. So I found it very nice and interesting.]

(Source: Interview, question 1, June 20, 2015) 
Pesquisadora: Houve algum aspecto positivo, além desse que você já falou? Ou alguma outra coisa que você achou positiva?

[Researcher: Was there any positive aspect, besides the one you have already mentioned? Something else you found positive?]

\section{Excerpt 10}

Cecília: Que ele [Paulo] tem bastante ideias. Então, assim, ele ajudou muito para criar uma bistória por trás daquela rotina ali. Então, acho que isso é um lado positivo, porque ele [Paulo] tem muitas ideias e ajuda bastante. [Cecília: That he [Paulo] has many ideas. So he really helped to create a story behind that routine. So I think this is positive, because he [Paulo] has many ideas and that helps a lot.] (Source: Interview, question 2, June 20, 2015)

In order for learners to benefit, they need to be open to interacting with others, so that comprehensible input can become intake (DONATO, 1994; FIGUEIREDO, 2015; SCARCELLA; OXFORD, 1992). Thus, their affective filter must be low, that is, they must have high motivation and low anxiety to avoid hindrances to their learning (ELLIS, 1985; KRASHEN, 1985, as cited in FIGUEIREDO, 2015; MCLAUGHLIN, 1987). People that have positive attitudes towards learning a second language will learn it more easily. As Lightbown and Spada (1993) point out, a facilitating environment can considerably contribute for learners' language development. Mclaughlin (1987, p. 48-49) highlights "the importance of creating an environment in the classroom that promotes realistic communicative use of language."

The kind of activity that was done by the students of this research portrays how important it is for learners to interact with each other, as through their interactions they have the opportunity to access input and produce output. Besides that, as they had known each other and studied together for around two years, their environment contributed to keeping their affective filters low, which led them to feel comfortable to speak freely, and thus generated more language production. According to Ellis (1985, p. 279), situational factors, "(i.e., who is addressing whom, when, about what, and where)", are paramount, as they influence learners' target language use. In an environment like the one depicted in this study, the context and their interlocutors favor students' language learning process.

Collaborative learning creates opportunities for students to share ideas and information (FIGUEIREDO, 2006, 2015; STORCH, 2005). Not only Gina and Cecília, in excerpts 08, 09 and 10, but also the other eight students recognized their peers' contributions to the development of the task as well as to their own language learning development. Scaffolding is present, as mutual support, throughout 
all interactions, aspect that was acknowledged by all the students during the interviews. As Figueiredo (2005) claims, through collaborative dialogue, language use and language learning can occur. By observing the students' attitudes towards their peers', one can clearly notice that they were open to receiving possible contributions from their classmates, aspect that characterizes a collaborative learning environment (SILVA; FIGUEIREDO, 2006).

In collaborative activities done in pairs or groups, students are led to assume the responsibility for their own learning and usually engage themselves in contributing to their peers' language development (DOBAO, 2012; FIGUEIREDO, 2006; FIGUEIREDO; ASSIS, 2006; STORCH, 2005). According to Figueiredo (2006, p. 19, emphasis in original), in collaborative learning, "[...] students choose their own roles, decide bow and what each one will do." ${ }^{18}$ Students are the ones that set the goals in the activity proposed by the teacher, and each one of them contributes with specific aspects of the language construction and of the task.

They perform active and reflective roles, when they exchange ideas and information, clear up doubts, interact by using the target language and collaborate with each other's language learning process. These aspects are observable in the previous subsection, in which the learners' interactions were discussed, as well as in the interviews, as one can see in excerpts 08,09 and 10.

In collaborative learning situations, students might experience positive interdependence (DONATO, 1994; FIGUEIREDO, 2008; OXFORD, 1997; RUBIN, 1987), that is, opportunities to achieve cognitive and social development through collaborative, dialogic interactions. For Scarcella and Oxford (1992, p. $35)$, students give valuable assistance to each other, as they "help one another on a variety of levels; for example, in addition to helping their peers with language, students also help their peers by providing them with information, responding to their ideas, and giving them needed encouragement". Gina's and Cecilia's answers to the interview, in excerpts 08, 09 and 10, show the relevance to get and receive help, as students have access to more ideas and possibilities, as well as the fact of having somebody else who is willing to help them monitor their performance, thus providing each other with corrections at important moments.

Hall (2001) also mentions that by promoting students' interaction in class, teachers encourage learners to appropriate different roles. As Figueiredo and Assis (2006) claim, when students work collaboratively, as in the context in question, they perceive they are in the same situation as their peers, that is, all of them are learners

8. Original quote: "[...] os alunos escolhem os seus papéis, decidem como e o que irão realizar" (FIGUEIREDO, 2006, p. 19, grifo no original). 
in that situation, which can make them feel more comfortable to express themselves in the target language. By doing so, learners' interactions have the potential to boost their self-esteem and self-confidence (FIGUEIREDO, 2005, 2006, 2008; FIGUEIREDO; ASSIS, 2006; LAGO, 2011), as they realize they possibly have mastery over some aspects of the language they are learning, which they can then share with others who do not.

In Hall's words (2001, p. 29), interactional activities "promote the development of interpersonal bonds among learners", improving their relationships. For Hall (2001) and Figueiredo and Assis (2006), besides sharing knowledge and different perspectives, through their interactions, students can support each other, which can lead to a positive emotional energy among them, and might trigger an even bigger interest in learning and the creation of a safe space. As Lago (2017, p. 307) states, when "students help each other mutually, in an atmosphere of reciprocal respect and encouragement, their collaborative work might substantially contribute to $[\ldots]^{\prime \prime}$ their language learning process.

In this study, the students' attitudes towards one another helped them create the positive atmosphere the authors mention, and that was an important element that contributed to the learners' recognition and receptiveness to their peers' corrections and other contributions.

In the following excerpts, the negative aspects mentioned by the students are addressed:

Pesquisadora: Houve algum aspecto negativo? Se sim, qual?

[Researcher: Was there any negative aspect? If so, which one?]

\section{Excerpt 11}

Carolina: Negativo? Ah, teve coisas que eu coloquei no texto com as quais eu não concordei, porém alguém tem que ceder. Então, para mim, o aspecto negativo é, assim, quando as ideias não batem, né? Por exemplo, escolher a ordem [das imagens]. Teve alguma coisa na ordem com a qual eu não concordei. Eu acho que ficaria melhor de outra forma, porém para entrar num acordo e sair a história, então, alguma coisa eu tive que ceder, né? Para mim, [esse] foi o aspecto negativo.

[Carolina: Negative? Ah, there were some things we used in the text with which I didn't agree, but somebody's got to give in. So, for me, the negative aspect is when the ideas aren't the same, right? For example, choosing the order [of the images]. There was something in the order with which I didn't agree, so I had to give in, right? For me, that was the negative aspect.] 


\section{Excerpt 12}

Alice: De vez em quando nós discordamos um pouco, porque cada uma queria uma coisa para a bistória.

[Alice: Sometimes we disagreed a little, because each one of us wanted something different for the story.]

(Source: Interview, question 3, June 20, 2015)

Alice, Carolina, Cecília, and Gina were the only students that perceived negative aspects in relation to the experience. Excerpts 11 and 12 encompass the general aspects highlighted by them. According to Figueiredo (2005, 2006, 2008), interactions between learners can lead to disagreements and conflicts, as it happened in Carolina's and Alice's cases. However, by doing a collaborative writing activity, students can develop their ability to work with others, that is, to work with people that have different ideas and points of view (FIGUEIREDO, 2006, 2008). Students decide what to do together, how to solve the problems that come up during their interactions, in a way decisions are made together (FIGUEIREDO, 2006).

It is important to emphasize that the problems students had during their interactions, that is, the disagreements and conflicts, are a part of any kind of human interaction, are a part of the language use itself and the social processes in which students participate daily. In everyday life, everyone has to deal with things with which they might not agree. People are different, and therefore have different ideas and points of view. The conflicts and disagreements the students of this study mention show that their interactions were authentic and their communication spontaneous. When students face conflicts, they are forced to adapt and to create news ways of dealing with dissent. Therefore, disagreements can be productive. Conflicts should not be perceived as something negative by language teachers, because they simply reflect what happens in real communication. It is this kind of genuine interaction we want our students to partake in, and not artificial ones.

\section{FINAL CONSIDERATIONS}

The main elements that stand out in the learners' interactions are: a) their co-construction of knowledge and negotiation, mainly of form; b) other-regulation and their positive attitudes towards their classmates' corrections; c) their repetition of each other's utterances, as a kind of strategy; d) the functions of output; e) private speech and self-regulation; f) the use of their L1 as scaffolding; g) the use 
of metalanguage ${ }_{i}$ h) the teacher's participation as a mediator; and i) the students' engagement and interest in each other's language learning development.

This study reinforces many elements presented by authors whose work focuses on collaborative language learning. When developing activities such as the one done in this research, the items listed are likely to show up. Nonetheless, it is relevant to mention some specificities of the context at hand: the students probably concentrated on the negotiation of form because this is one of the main elements demanded from them by teachers at that institution; it is perceivable that they felt comfortable to correct each other and rely on one another possibly because of the atmosphere previously created by the group and also due to their two years together as classmates; as everything led the interactions to be fruitful, by interacting with their peers, they realized the importance of expressing themselves in English for their cognitive and sociolinguistic development; and the fact they have the same L1 (Portuguese) and that they are allowed to use it in class was also beneficial for their interactions.

All participants of this study perceived the same positive aspects in relation to the experience. The learners recognized their mutual support in order to carry out the activity and to aid each other's language development. Furthermore, they underscored that when they work in collaboration, they have access to more ideas and alternatives to create their texts. On the other hand, only four students mentioned negative aspects, which were disagreements and conflicts they had to handle during their interactions; aspects that, nonetheless, indicate that their communication was authentic.

The kind of activity done with the students that participated in this study is an example that involves both production and comprehension, as encouraged by Mclaughlin (1987). What the learners did involves the four skills - listening, speaking, reading and writing -, in an integrated way. In addition, this kind of activity grants them more autonomy. As Rubin $(1987$, p. 17) claims, "it is essential for language students to begin to take control of their learning." Finally, as it was possible to see throughout this study, collaboration and interaction in class can make all the difference in students' language learning process.

\section{REFERENCES}

ALJAAFREH, A.; LANTOLF, J. P. (1994). Negative Feedback as Regulation and Second Language Learning in the Zone of Proximal Development. The Modern Language Journal, v. 78 , n. 4, pp. 465-483. 
BELL, J. (2008). Projeto de Pesquisa: Guia para pesquisadores iniciantes em educação, saúde e ciências sociais. 4. ed. Porto Alegre, RS: Artmed/Bookman.

COOK, V. (1999). Going beyond the native speaker in language teaching. TESOL Quarterly, v. 33, n. 2, pp. 185-209.

CORDER, S. P. (1967). The significance of learners' errors. IRAL - International Review of Applied Linguistics in Language Teaching, v. 5, n. 4, pp. 161-170.

DENZIN, N. K.; LINCOLN, Y. S. (2003). Introduction: The discipline and practice of qualitative research. In: DENZIN, N. K.; LINCOLN, Y. S. (Ed.). Strategies of qualitative inquiry. Thousand Oaks, CA: Sage, pp. 1-45.

DIONÍSIO, Â. P. (2001). Análise da conversação. In: MUSSALIM, F.; BENTES, A. C. (Org.). Introdução à linguística: domínios e fronteiras. 1. ed. São Paulo: Cortez, pp. 69-99.

DOBAO, A. M. F. (2012). Collaborative writing tasks in the L2 classroom: Comparing group, pair, and individual work. Journal of Second Language Writing, v. 21, n. 1, pp. 4058.

DONATO, R. (1994). Collective scaffolding in second language learning. In: LANTOLF, J. P.; APPEL, G. (Ed.). Vygotskian Approaches to Second Language Learning. Norwood, N. J.: Ablex Publishing Company, pp. 33-56.

ELLIS, R. (1985). Understanding Second Language Acquisition. Oxford: Oxford University Press.

FIGUEIREDO, F. J. Q. (1999). Aprendizagem de uma segunda língua: a relação erro X comunicação. In: BIGONJAL-BRAGGIO, S. L. (Org.). Contribuições da Linguística para o Ensino de Linguas. Goiânia: Ed. da UFG, pp. 79-93.

FIGUEIREDO, F. J. Q. (2005). Semeando a interação: A revisão dialógica de textos escritos em língua estrangeira. Goiânia: Ed. Da UFG.

FIGUEIREDO, F. J. Q. (2006). A aprendizagem colaborativa de línguas: algumas considerações conceituais e terminológicas. In: FIGUEIREDO, F. J. Q. (Org.). A aprendizagem colaborativa de línguas. Goiânia: Ed. da UFG, pp. 11-45.

FIGUEIREDO, F. J. Q. (2008). The influences of collaboration on the learning of a foreign language. MOARA, n. 30, pp. 117-134. 
FIGUEIREDO, F. J. Q. (2015). Aprendendo com os erros: uma perspectiva comunicativa de ensino de línguas. 3. ed. Goiânia: Editora UFG.

FIGUEIREDO, F. J. Q.; ASSIS, N. A. L. (2006). A auto-estima e a atitude quanto à escrita na revisão colaborativa. In: FIGUEIREDO, F. J. Q. (Org.). A aprendizagem colaborativa de línguas. Goiânia: Ed. da UFG, pp. 165-199.

GODOY, A. (2006). Estudo de caso qualitativo. In: GODOI, C.; BANDEIRA-DEMEllo, R.; BARBOSA DA SILVA; A. (Org.). Pesquisa Qualitativa em Estudos Organizacionais: Paradigmas, Estratégias e Métodos. São Paulo: Saraiva, pp. 115-146.

HALL, J. K. (2001). Classroom interaction and language learning. Ilha do Desterro, Florianópolis, n. 41, pp. 17-39.

HARRIS, M. (1992). Collaboration Is Not Collaboration Is Not Collaboration: Writing Center Tutorials vs. Peer-Response Groups. College Composition and Communication, v. 43, n. 3, pp. 369-383.

JORDÃO, C. (2014). M. ILA - ILF - ILE - ILG: quem dá conta? Revista Brasileira de Linguística Aplicada (RBLA), v. 14, n.1, pp. 13-40.

KUMARAVADIVELU, B. (2012). Individual identity, cultural globalization, and teaching English as an international language: the case for an epistemic break. In: ALSAGOFF, L.; MCKAY, S. L.; HU, G.; RENANDYA, W. A. (Ed.). Principles and practices for teaching English as an international language. New York: Francis and Taylor, pp. 9-27.

LAGO, N. A. (2011). Um olhar pelos recônditos: fatores afetivos e aprendizagem de línguas estrangeiras. In: CRUZ, N. C.; PINHEIRO-MARIZ, J. (Org.). Ensino de línguas estrangeiras: contribuições teóricas e de pesquisa. Campina Grande: EDUFCG, pp. 11-36.

LAGO, N. A. (2017). Understanding metaphorical texts in foreign literature. Humanities and Social Sciences Review, v. 7, n. 1, pp. 297-308.

LANTOLF, J. P.; APPEL, G. (1994). Theoretical framework: an introduction to Vygotskian approaches to second language research. In: (Ed.). Vygotskian Approaches to Second Language Research. New Jersey: Ablex Publishing Corporation, pp. 1-32.

LIGHTBOWN, P. M.; SPADA, N. (1993). How languages are learned. Hong Kong: Oxford University Press, pp. 1-17. 
MCLAUGHLIN, B. (1987). Theories of Second-Language Learning. New York: Edward Arnold, pp. $19-58$

MELLO, H. A. B.; REES, D. K. (2011). A investigação etnográfica na sala de aula de segunda língua/ língua estrangeira. Cadernos do IL, n. 42, pp. 30-50.

OXFORD. R. L. (1990). Language Learning Strategies: what every teacher should know. Boston, MA: Heinle \& Heinle Publishers, pp. 1-22.

OXFORD. R. L. (1997). Cooperative learning, collaborative learning, and interaction: Three communicative strands in the language classroom. The Modern Language Journal, v. 81, n. 4 , pp. $443-456$.

RICHARDS, J. C.; LOCKART, C. (1996). Reflective Teaching in Second Language Classrooms. Cambridge: Cambridge University Press, pp. 6-28.

RUBIN, J. (1987). Learner strategies: theoretical assumptions, recent history and typology. In: WENDEN, A.; RUBIN, J. (Ed.). Learner Strategies in Language Learning. New York: Prentice Hall, pp. 15-30.

SCARCELLA, R. C.; OXFORD, R. L. (1992). The Tapestry of Language Learning. Boston: Heinle \& Heinle Publishers.

SILVA, S. V.; FIGUEIREDO, F. J. Q. (2006). Erro e correção: as crenças de dois professores de escola pública e de alguns de seus alunos. Revista Brasileira de Linguística Aplicada, v. 6, n. 2, pp. 113-141.

STORCH, N. (2001). How collaborative is pair work? ESL tertiary students composing in pairs. Language Teaching Research, v. 5, n. 1, pp. 29-53.

STORCH, N. (2005). Collaborative writing: Product, process, and students' reflections. Journal of Second Language Writing, v. 14, n. 3, pp. 153-173.

SWAIN, M. (1995). Three Functions of Output in Second Language Learning. In: COOK, G.; SEIDLHOFER, B. (Ed.). Principle \& Practice in Applied Linguistics. Oxford: Oxford University Press, pp. 125-144.

TELLES, J. A. (2002). "É pesquisa, é? Ah, não quero, não bem!" Sobre a pesquisa acadêmica e a sua relação com a prática do professor de línguas. Linguagem e Ensino, v. 5, n. 2, pp. 91-116. 
VYGOTSKY, L. S. (1978). Mind in Society: the Development of Higher Psychological Processes. Cambridge, MA: Harvard University Press.

WATCYN-JONES, P. (2001). Vocabulary 1: Games and Activities. Essex, England: Penguin Books, pp. 59.

WOOD, D.; BRUNER, J. S.; ROSS, G. (1976). The Role of Tutoring in Problem Solving. Journal of Child Psychology and Psychiatry, v. 17, pp. 89-100. 


\section{APPENDIX $A^{9}$}

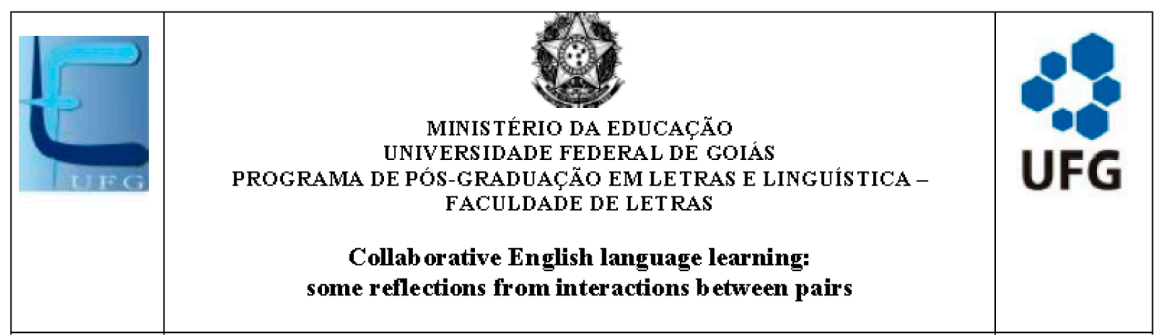

\section{Initial questionnaire}

Goiânia, 2015.

Name:

Pseudonym: Age: Sex:

1) Do you enjoy writing? Why (not)?

2) Have you ever written a text in pairs? If you have, how was it? If you have not, how do you think it would be?

9. The questions in this questionnaire were originally asked in Portuguese due to the fact students could have difficulties to express themselves in English, as they were elementary students. In addition, this source was used to gather data related to their experiences and perceptions, and not to analyze their linguistic development in English. 


\section{APPENDIX $B^{10}$}

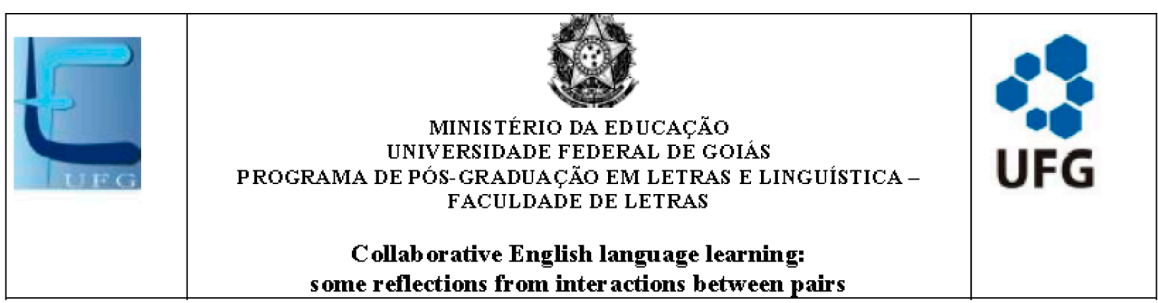

\section{Interview}

Goiânia, 2015 .

Name:

Pseudonym:

1) What do you think of the activity you did in pairs?

2) Were there any positive aspects? If so, which ones?

3) Were there any negative aspects? If so, which ones?

4) What are the differences between writing in pairs and doing it alone?

5) Taking into account that the activity was done in pairs, share how the development of the following aspects was, during the writing production:
a) grammar;
b) vocabulary;
c) text structure;
d) any other aspect (you would like to add)?

10. The questions in this interview were originally asked in Portuguese due to the fact students could have difficulties to express themselves in English, as they were elementary students. Besides that, this source was used to record data related to their perceptions and discourses regarding the experience. 


\section{ANNEX A}

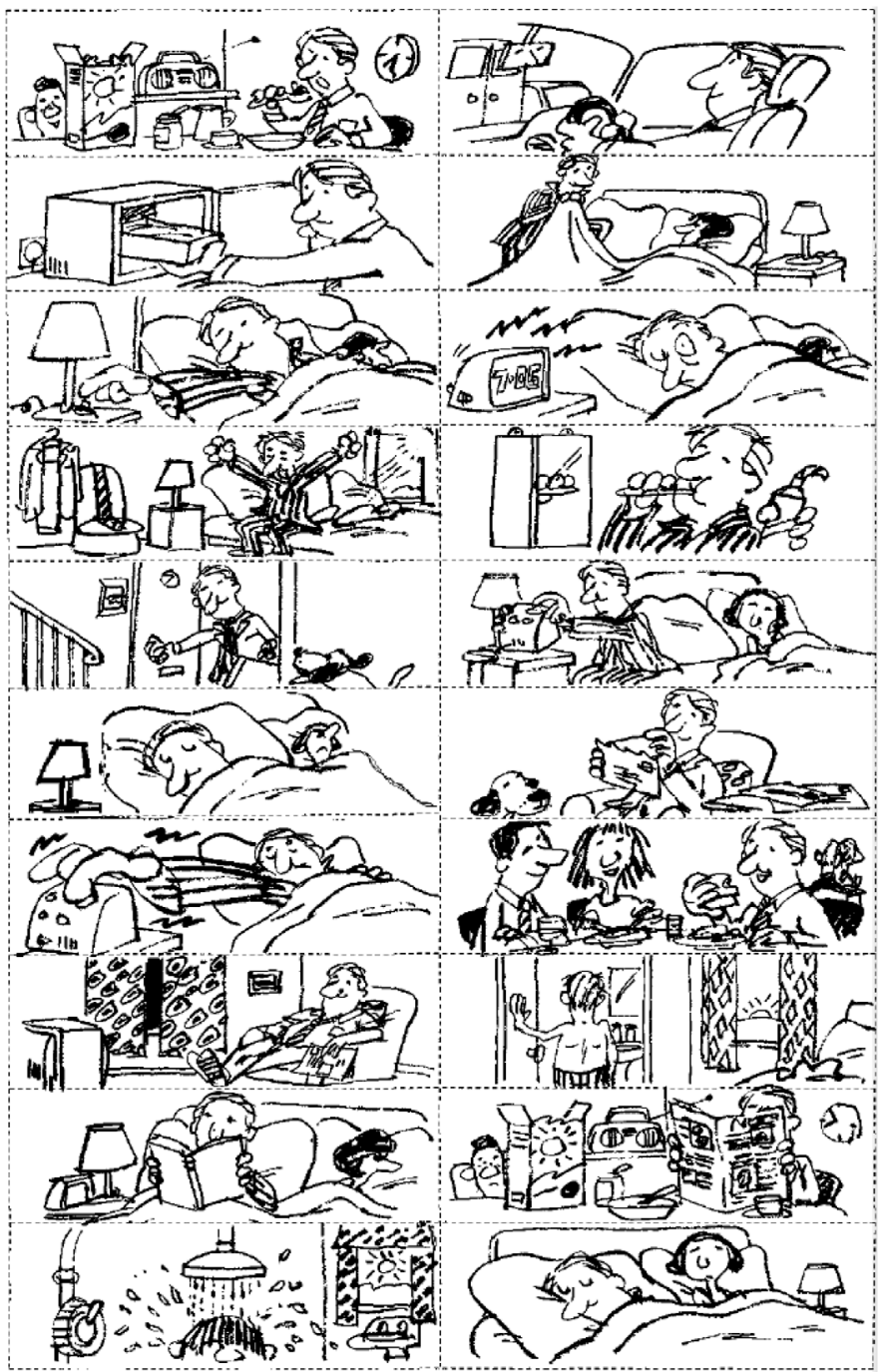

Adapted from:WATCYN-JONES, P. (2001). Vocabulary 1: Games and Activities. Essex, England: Penguin Books, pp. 59.

Recebido: 17/09/2018

Aceito: 9/01/2019

Publicado: 29/03/2019 